\title{
Annual tree rings in Piptadenia gonoacantha (Mart.) J.F.Macbr. in a restoration experiment in the Atlantic Forest: potential for dendroecological research
}

\author{
Arno Fritz das Neves Brandes ${ }^{\star *}$, Rafael Perpetuo Albuquerque ${ }^{2}$, Luiz Fernando Duarte de Moraes ${ }^{3}$ \\ and Cláudia Franca Barros ${ }^{2}$
}

Received: March 28, 2016

Accepted: June 13, 2016

\begin{abstract}
The tree Piptadenia gonoachantha is widely used in forestry and in forest restoration projects, which require methods for evaluating tree growth. Long-term studies are necessary to determine patterns and detect changes in species growth rhythms. Tree ring analysis provides a precise method for determining age and documenting long-term growth trends in tropical tree species. The present study evaluated the periodicity of tree ring formation and radial growth dynamics of $P$. gonoachantha from a population of known age in the Poço das Antas Biological Reserve. Two radii from six trees were sampled using non-destructive methods. Tree rings were counted and measured to estimate age and to calculate diametric increment. All samples had 16 tree rings, which matched the known plantation age and confirmed the annual formation of rings. The individuals sampled had a mean annual diametric increment of 9.5 $\mathrm{mm}$ / year. Results showed a trend towards decreasing growth rate with increasing age. Individuals of $P$. gonoachantha in Ombrophilous Dense Forest produce annual tree rings, which holds potential for future dendroecological studies.
\end{abstract}

Keywords. Atlantic Forest, dendrochronology, growth rhythm, growth rings, Leguminosae, Ombrophilous Dense Forest, Pau-jacaré, Piptadenia gonoacantha, reforesting, restoration.

\section{Introduction}

Historical information about forest growth is essential for understanding and evaluating changes in both natural and managed forests, and may be useful for forest restoration (Biondi 1999). Estimates of age and radial growth of woody species are usually carried out by applying indirect shortterm methods, including periodic measurements of trunk diameter in forest inventories. Inventories that quantify growth of individual trees and the forest as a whole can provide insight into forest dynamics at the population and community levels, but they are often temporally limited, and may cover only a few years or decades (Biondi 1999). Moreover, these methods do not always produce reliable results (Martínez-Ramos \& Alvarez-Buylla 1998). On the other hand, tree-ring analysis has proven to provide accurate data for assessing age and growth of tree species over long periods of time (Worbes 1999; Worbes \& Junk 1999; Roig 2000; Brienen \& Zuidema 2006; Rozendaal et al. 2011).

Planting of native tree species has been used successfully in ecological restoration, with the aim of catalyzing forest

\footnotetext{
${ }^{1}$ Departamento de Biologia Geral, Instituto de Biologia, Universidade Federal Fluminense, Campus Valonguinho, Outeiro de São João Batista, S/N, 24020-141, Niterói, RJ, Brazil

${ }^{2}$ Instituto de Pesquisas Jardim Botânico do Rio de Janeiro, Rua Pacheco Leão, 915, 22230-030, Rio de Janeiro, RJ, Brazil

${ }^{3}$ Empresa Brasileira de Pesquisa Agropecuária, Agrobiologia, Rod. BR 465, km 3.5, 23890-000, Seropédica, RJ, Brazil

* Corresponding author: arnofritz@id.uff.br
} 
succession and accelerating the recovery processes (Moraes et al. 2006; Sansevero et al. 2011). In the 1990s, native tree species were planted to restore degraded Atlantic Forest in the Poço das Antas Biological Reserve (Reserva Biológica de Poço das Antas). Evaluations of these plantations consisted of estimating the survival rate of planted saplings (after one year), annual measurements of trunk diameter and height (for the first 3 or 4 years) and studies on the structure of the regenerating plant community (after $9-11$ years) (Moraes et al. 2006; Sansevero et al. 2011). These results provided important, although limited, information on survival, growth and regeneration rates for Atlantic Forest plantations. To complement and extend this data, these authors recommended long-term evaluations to provide a better understanding of the ecological dynamics of the area under recovery.

One of the species established in experimental plantations at Poço das Antas was Piptadenia gonoacantha (Leguminosae) (Sansevero et al. 2011), a species widely used in forestry and forest restoration. Recommended uses of this species include the production of lumber, energy, cellulose and paper, tannin and animal feed, apiculture and landscaping (Carvalho 2004). Piptadenia gonoacantha is either a semi-deciduous (Carvalho 2004; Lisi et al. 2008) or deciduous species (Pereira et al. 2008; TS Pereira unpubl. res.). It is a nitrogen fixing heliophile, and can be a pioneer or a climax species, reaching up to 30 meters in height and $90 \mathrm{~cm}$ in diameter at breast height (DBH). It is widely distributed throughout the Brazilian Atlantic Forest, including Ombrophilous, Deciduous and Semideciduous Forests, and the Cerrado (savanna) (Carvalho 2004; Piptadenia in Flora do Brasil 2020 em construção).

This species has distinct tree rings marked by semiring porous, thick-walled and radially flattened fibers on latewood (fibrous zone) and marginal parenchyma (Evans et al. 2006; Lisi et al. 2008; Longui et al. 2009), indicating its potential for dendrochronological research. However, dendrochronological investigation requires prior evaluation of the frequency of tree ring formation. Several methods exist for such an assessment, including: cambium wound, dendrometers, radiocarbon analysis, tree-ring analysis of individuals of known age, cross-dating and correlations between tree-ring chronologies and climate data (Worbes 1995). Lisi et al. (2008) used cambium wounds and dendrometric bands to determine the existence of annual tree rings in this species in a Semideciduous Forest, but studies evaluating periodicity in this species have not yet been developed in regions of Ombrophilous Dense Forest. Because environmental conditions are different in these two forest types (Lima et al. 2006; Lisi et al. 2008), there is potential that tree ring formation also differs (Hayden et al. 2010). Therefore, the aim of this study was to assess the periodicity of tree-ring formation and radial increment in $P$. gonoacantha growing in a plantation of known age in Poço das Antas Biological Reserve, in order to support future dendrochronological studies in Ombrophilous Dense Forest and, in particular, radial growth assessments used in studies on forest dynamics and forest restoration.

\section{Materials and methods}

\section{Study area}

Poço das Antas Biological Reserve, located in Silva Jardim, Rio de Janeiro, Brazil, (22 ${ }^{\circ} 30^{\prime}$ to $22^{\circ} 33^{\prime}$ S and $42^{\circ} 15^{\prime}$ to $42^{\circ} 19^{\prime} \mathrm{W}$ ), covers an area of approximately 5,000 hectares in the Atlantic Forest biome (Fig. 1A-B). The vegetation type is Ombrophilous Dense Forest with two forest formations: sub-montane forest and alluvial forest (Lima et al. 2006). About half of the area of the reserve consists of disturbed areas in different successional stages. The local landscape includes periodically flooded lowlands and 19 to $200 \mathrm{~m}$-high rounded hills. The climate is tropical with a dry winter (Aw, according to the Köppen System), with an average annual rainfall of $1995 \mathrm{~mm}$, and an average annual temperature of $25.5^{\circ} \mathrm{C}$ (Lima et al. 2006; Moraes et al. 2006). During the dry season (winter) from 1984-2007, the mean monthly rainfall was $52.0 \mathrm{~mm}, 72.6 \mathrm{~mm}$ and $55.8 \mathrm{~mm}$, for June, July and August, respectively (Fig. 1C). Sampling was carried out in an experimental area of native species planted in 1996, including P. gonoacantha (Mart.) J.F.Macbr.

\section{Wood sampling}

Stem cores were sampled in six individual trees of $P$. gonoacantha (Tab. 1) in a 1.0 ha mixed native tree plantation. The plantation is located on slopes ranging from $23^{\circ}$ to $25^{\circ}$, and used a $2 \mathrm{~m} \times 2 \mathrm{~m}$ spacing and a planting density of 2,500 individuals/ha (Sansevero 2008; Sansevero et al. 2011). Local soils are acidic and have high levels of aluminum (Moraes et al. 2008). Wood sampling was carried out in April 2012, using a Pressler borer (non-destructive method) to withdraw two cylindrical samples (radii) of wood at approximately $1.3 \mathrm{~m}$ above the ground and $180^{\circ}$ from each other. A Bordeaux mixture (CuSO) was applied to the wound after sample removal to prevent attack and infection by pathogens (Pscheidt \& Ocamb 2016). Trees selected for study had no apparent deformities or irregularities on the trunk near to where the samples were taken. Diameter at breast height (DBH) was measured with a diameter tape. The collected material was held at Laboratório de Botânica Estrutural, Diretoria de Pesquisas, Instituto de Pesquisas Jardim Botânico do Rio de Janeiro. The wood samples were deposited in the wood collection of the Instituto de Pesquisas Jardim Botânico do Rio de Janeiro (RBw).

\section{Sample processing and measurement}

Samples were glued in wooden supports and then polished with an orbital sander (Raimann) using a 

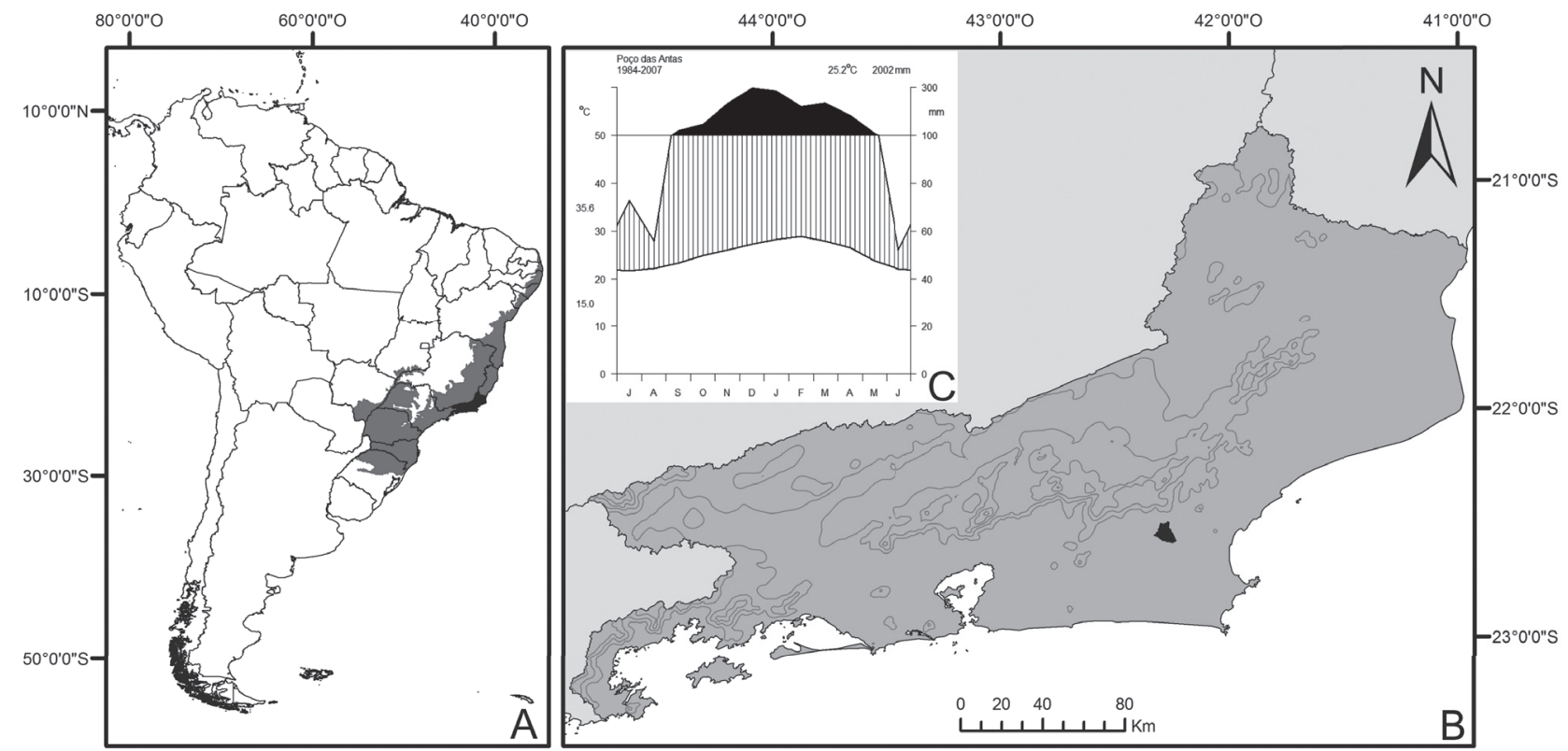

Figure 1. A. Map of South America. Gray = Atlantic Forest biome. Black = Rio de Janeiro State. B. Map of Rio de Janeiro State. Gray = Atlantic Forest biome. Black = Poço das Antas Biological Reserve. Grey lines = altimetry each 400 meters. C. Climate diagram (Walter \& Lieth 1960) based on data from the Meteorological Station Programa Mata Atlântica in Poço das Antas Biological Reserve (1984 to 2007).

Table 1. Sample list. $\mathrm{DBH}=$ diameter at breast height; $\mathrm{MAI}=$ mean annual diametric increment; $\mathrm{SD}=$ standard deviation; $\mathrm{AI}$ Max = maximum annual diametric increment; AI Min = minimum annual diametric increment.

\begin{tabular}{|l|c|c|c|c|c|}
\hline Sample & DBH & MAI & SD & Al Max & AI Min \\
\hline RBw10272 & 24.1 & 13.6 & 5.6 & 25.0 & 4.0 \\
\hline RBw10273 & 20.4 & 11.5 & 4.9 & 23.3 & 3.2 \\
\hline RBw10274 & 16.8 & 9.7 & 3.6 & 13.9 & 2.6 \\
\hline RBw10275 & 14.6 & 8.2 & 4.5 & 18.7 & 4.3 \\
\hline RBw10276 & 9.5 & 5.2 & 4.4 & 16.6 & 1.3 \\
\hline RBw10277 & 15.3 & 8.7 & 4.7 & 18.0 & 1.9 \\
\hline Mean & 16.8 & 9.5 & & & \\
\hline
\end{tabular}

progressive series of sandpaper (80 to 1200), to allow clear observation of tree-ring limits. Observations were made using a stereomicroscope (Leica). Both a camera attached to the stereomicroscope and a scanner (HP Scanjet 2400) were used for image capture. Counts and measurements of tree rings were performed using Image-Pro Plus software. Data assigned to the rings followed Schulman (1956), a convention for studies in the Southern Hemisphere, which assigns to each ring the year of the beginning of its formation. The annual radial increment was obtained by measuring the width of growth layers. For each individual, annual diametric increment was obtained by summing the width of the growth layers of the same year obtained from two radii. The mean annual diametric increment was calculated. Individual cumulative diametrical increment curves were constructed from the sum of the annual diametric increment. To emphasize changes in growth rate according to the age, the moving average was calculated using a 5-year window from the annual radial increment.

\section{Results}

Annual growth layers were found in P. gonoacantha marked by semi-ring porous, marginal parenchyma, and a fibrous zone (Fig. 2). In all samples (radii) of all trees, 16 tree rings were counted, precisely matching the age of the plantation, which confirms annual formation of the tree rings. Trees were planted in January 1996, and the sampling for this study was completed in April 2012. The last growth ring observed was formed in 2011, suggesting that the 2012-ring had not been formed by the collection date. No differences were found in the number of rings among radii of the same individual or among different individuals; missing and locally absent rings were not detected.

The analysis of tree-ring width, which provides the annual radial increment (Fig. 3), and moving average radial increase (Fig. 4) showed that the rate of radial growth decreased as trees aged. The mean annual diametric increment for the 


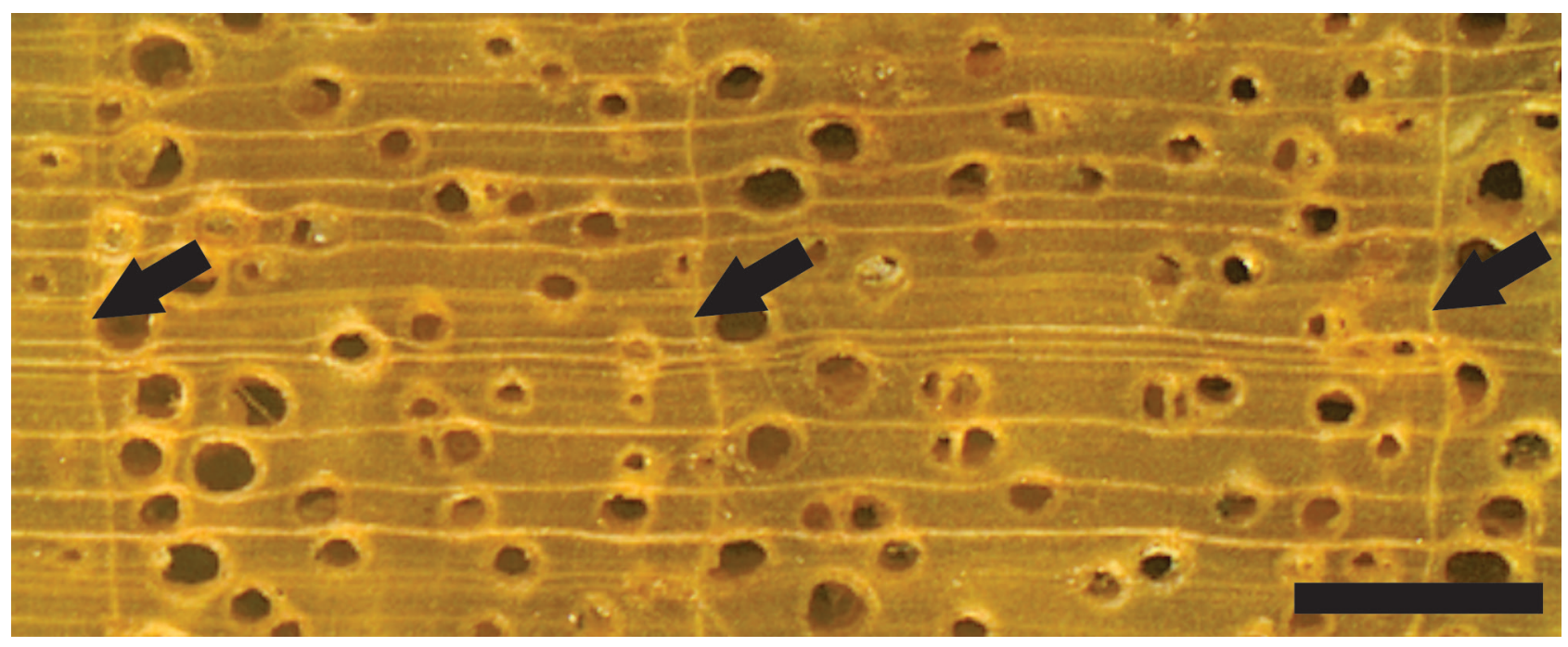

Figure 2. Transverse section (stereomicroscopy) of $P$. gonoacantha. Arrows indicate growth rings boundaries. Scale bar $=1 \mathrm{~mm}$.

species in the study area was calculated to be $9.5 \mathrm{~mm}$ / year. A remarkable difference in average annual diametric growth rate was noted among individuals, ranging from $5.2 \mathrm{~mm} /$ year to $13.6 \mathrm{~mm} /$ year (Tab. 1). This finding was confirmed by comparing cumulative diametric increment curves (Fig. 5) and DBH (Tab. 1). Individuals of the same age (16 years) had DBH ranging from $9.5 \mathrm{~cm}$ to $24.1 \mathrm{~cm}$.

\section{Discussion}

The results of this study showed that $P$. gonoacantha, in Ombrophilous Dense Forest, forms annual tree rings. Considering the studies of Lisi et al. (2008), who found similar results with this species growing in Semideciduous Forest, we may conclude that the species forms annual tree rings in different forest types, independently of site conditions, such as soil, landscape, annual rainfall, and mean temperature. Hayden et al. (2010) studied P. constricta submitted to different irrigation conditions in western Mexico and detected no effect on annual tree-ring formation, even with dry-season precipitation. The anatomical features observed in the individuals analyzed in our study corresponded to previous descriptions (Evans et al. 2006; Lisi et al. 2008; Longui et al. 2009). The observed results indicate potential for developing dendrochronological and dendroecological research in the Ombrophilous Dense Forest using this species.

The annual periodicity of tree-ring formation in $P$. gonoacantha in Ombrophilous Dense Forest can be related to two factors: seasonality in rainfall and seasonality in leaf drop. Much of the Atlantic Forest biome covers regions with an annual dry season (IBGE 2012; Alvares et al. 2014). According to Worbes (1995), a two or three month-dry season with less than $60 \mathrm{~mm}$ of monthly precipitation may induce formation of annual tree rings in tropical species, which was supported by our findings at the Poço das Antas
Biological Reserve. Moreover, P. gonoacantha is considered to be either a semideciduous (Carvalho 2004; Lisi et al. 2008) or a deciduous species. Pereira et al. (2008) and TS Pereira (unpubl. res.) performed a phenological study of the species in Poço das Antas Biological Reserve, and observed leaf fall from September to October, budding from October to December and blooming from January to April. Leaf shedding has been identified by authors as a influential factor in the seasonality of cambial activity, and therefore formation of annual tree rings (Borchert 1999).

Studies of other liana and tree species of the genus Piptadenia have also observed distinct annual growth rings (Brandes \& Barros 2008; Hayden et al. 2010), whith growth-ring chronologies having been built and growthprecipitation relationships having been recorded (Brandes et al. 2011).

Several studies have investigated relative growth performance of wild versus planted individuals of $P$. gonoacantha, but only two of these studies estimated radial increment based on tree-rings measurements. Growth of wild and planted $P$. gonoacantha were measured in a Semideciduous Forest in São Paulo State (Brazil), resulting in a mean annual girth increment of $17.9 \mathrm{~mm}$ for wild, and $19.1 \mathrm{~mm}$ for planted individuals (Lisi et al. 2008), In comparison with the results of our study, those values represent mean annual diametric increment of $5.7 \mathrm{~mm} /$ year and $6.1 \mathrm{~mm} /$ year, respectively. The authors, using dendrometers, found that radial growth reduced during dry seasons. Davide \& Faria (1997, apud Ferreira et al. 2007), and Ferreira et al. (2007) evaluated the growth of 4.8 yearold and 12.9 year-old individuals of $P$. gonoacantha, planted in a project to restore the riparian vegetation along the Rio Grande river, in the state of Minas Gerais (Brazil), and found an average annual increment in diameter of $24 \mathrm{~mm} /$ year and $27 \mathrm{~mm}$ / year, respectively. Those values are higher than those found in our study, and are inconsistent with 


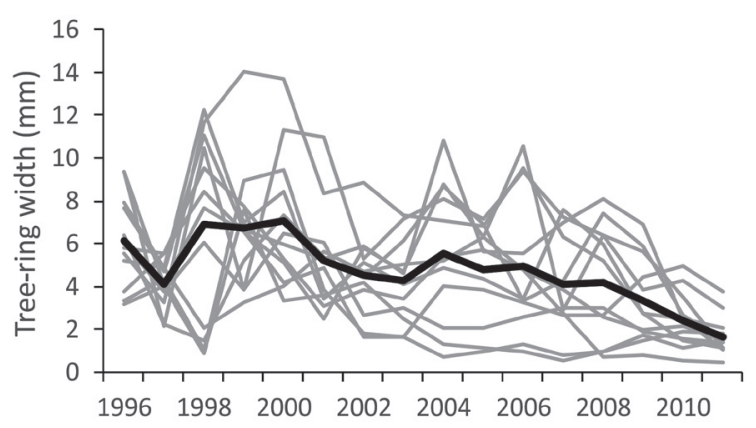

Figure 3. Tree-ring width time series (annual increment). Gray line $=$ samples. Black line $=$ average of all time series.

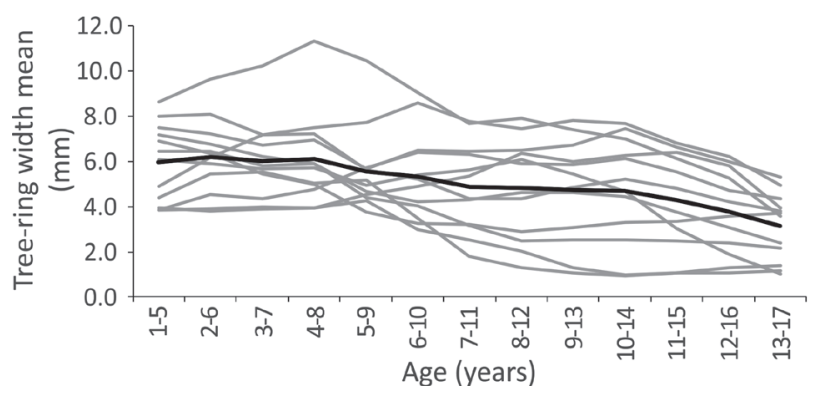

Figure 4. Moving average of tree ring width time series. Gray line $=$ samples. Black line $=$ average of all trees.

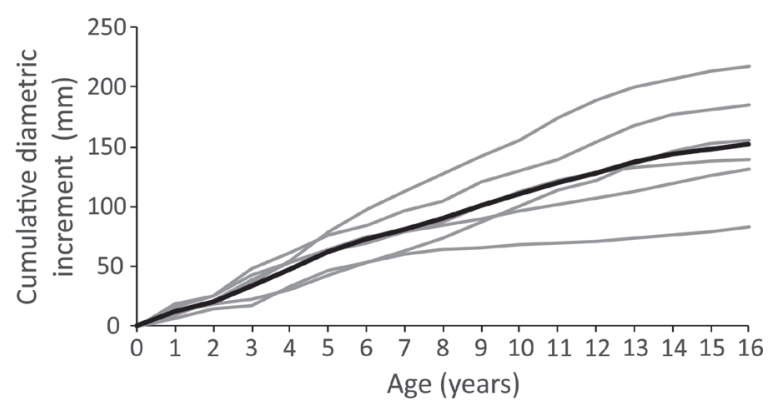

Figure 5. Cumulative diametric increment. Gray line = samples . Black line $=$ average of all time series.

our observations, as they recorded an increase in growth rate as the plantation aged. Carvalho (2004) reported on 18 plantation experiments with $P$. gonoacantha in southern and southeastern Brazil, with an average annual increase in diameter ranging from 6.4 to $34.1 \mathrm{~mm}$.

Brandes (2011), applying dendrochronology, analyzed mean annual radial increment of $P$. gonoacantha growing in the Montane Ombrophilous Dense Forest, and detected a value of $4.4 \mathrm{~mm}$ / year $(8.9 \mathrm{~mm} /$ year of annual diametric increment), a result very similar to the mean annual diametric increment found in the present study. Ferreira (2002) also studied the tree rings of $P$. gonoacantha in a Semideciduous Forest, and detected radial growth rates ranging from 3.6 to $8.4 \mathrm{~mm}$ / year (7.3 to $16.9 \mathrm{~mm}$ /year of annual diametric increment), with a mean value of $6.60 \mathrm{~mm} /$ year $(13.2 \mathrm{~mm} /$ year of annual diametric increment). Comparing our results with the growth rates observed in some of these studies for individuals growing both in the wild and in planted areas, we notice values that appear to be similar, even in places under different environmental conditions. The lowest growth rate reported for $P$. gonoacantha was recorded in a Semidecidual Forest by Lisi et al. (2008).

Although the studies presented above show that $P$. gonoacantha has significant variation in radial growth rates, the species demonstrates high growth rates in comparison to other species (Ferreira 2002; Carvalho 2004; TomazelloFilho et al. 2004; Ferreira et al. 2007; Brandes 2011). In other words, $P$. gonoacantha may be considered a fast growing species. This performance is expected for a heliophilic pioneer species. Evaluations carried out in plantations in Poço das Antas Biological Reserve indicated that pioneer species have higher diameter growth rates in the early years of life (Moraes et al. 2006), and our results confirm this finding.

The decrease in the diameter growth rate over time may be due to physiological and environmental conditions. This negative growth trend, known as "age trend", is common in open-canopy situations. It is associated with the geometrical consequence of adding the same wood volume to a stem with increasing radius, and with other factors including: increasing transport distances for nutrients, water and hormones; decreasing soil nutrient availability; altered balance in photosynthetic and respiring tissues and changes in allocation (Fritts 1976; Cook 1985; Weiner 2001). Agerelated growth trend has been reported for other tropical species in plantation experiments (e.g.: Worbes 1999; Costa et al. 2015).

Brandes (2011) analyzed growth releases in seven species of Leguminosae based on the tree rings. Growth release is an abrupt change in growth that is maintained during some years. Piptadenia gonoacantha had the fewest growth releases among the species studied, indicating that few abrupt changes occur in the growth of this species during its lifespan. This trend has been observed in other shadeintolerant species, which are expected to spend most of their lives without drastic changes in the amount and intensity of light, while shade tolerant species can experience diverse forest events resulting in changes in light availability, and affecting plant growth (Baker \& Bunyavejchewin 2006).

The results presented represent the first information about growth of P. gonoacantha in the Poço das Antas Biological Reserve. Previous evaluations estimated survival rates of planted saplings, analyzed structure of a regenerating plant community and evaluated growth in diameter and height of some planted species (not including P. gonoacantha) over three or four years (Moraes et al. 2006; Sansevero et al. 2011). The result of this study will help to better understand growth dynamics in plantation experiments and could be employed in future forest restoration projects in the Ombrophilous Dense Forest.

This study applied tree-ring analysis to assess the growth dynamics of $P$. gonoacantha. The analysis of tree rings showed 
that radial growth rate is not constant, but fluctuates over the lifespan of the plant. Furthermore, radial growth rate differs widely among individuals, although short-term studies are likely insufficient for detecting this variance.

We conclude that planted individuals of $P$. gonoacantha in the Ombrophilous Dense Forest form annual tree rings, which can be used to assess a species' growth and provide an accurate view of radial increment performance.

\section{Acknowledgments}

We acknowledge Andrea Sánchez-Tapia, Adilson Martins Pintor and Reserva Biológica de Poço das Antas for help and support in field collection. Programa de Pesquisa em Biodiversidade (PPBio), Conselho Nacional de Desenvolvimento Científico e Tecnológico (CNPq), Projeto Nacional de Ações Integradas Público-Privadas para Biodiversidade (Probio II), Coordenação de Aperfeiçoamento de Pessoal de Nível Superior (CAPES), Fundação de Amparo à Pesquisa do Estado do Rio de Janeiro (FAPERJ) and Global Environment Facility (GEF) provided financial support for this research.

\section{References}

Alvares CA, Stape JL, Sentelhas PC, Gonçalves JLM, Sparovek G. 2014. Köppen's climate classification map for Brazil. Meteorologische Zeitschrift 22: 711-728.

Baker PJ, Bunyavejchewin S. 2006. Suppression, release and canopy recruitment in five tree species from a seasonal tropical forest in western Thailand. Journal of Tropical Ecology 22: 521.

Biondi F. 1999. Comparing tree-ring chronologies and repeated timber inventories as forest monitoring tools. Ecological Applications 9: 216-227.

Borchert R. 1999. Climatic periodicity, phenology and cambium activity in tropical dry forest trees. Iawa Journal 20: 239-247.

Brandes AFN. 2011. Dendrocronologia e dendroecologia de árvores e lianas da família Leguminosae na Mata Atlântica. PhD Thesis, Instituto de Pesquisas Jardim Botânico do Rio de Janeiro, Brazil.

Brandes AFN, Lisi CS, Barros CF. 2011. Dendrochronology of lianas of the Leguminosae family from the Atlantic Forest, Brazil. Trees 25: 133-144.

Brandes AFN, Barros CF. 2008. Anatomia do lenho de oito espécies de lianas da família Leguminosae ocorrentes na Floresta Atlântica. Acta Botanica Brasilica 22: 465-480.

Brienen RJW, Zuidema PA. 2006. The use of tree rings in tropical forest management: Projecting timber yields of four Bolivian tree species. Forest Ecology and Management 226: 256-267.

Carvalho PER. 2004. Pau-Jacaré - Piptadenia gonoacantha. Circular Técnica Embrapa 91: 1-12.

Cook ER. 1985. Time series analysis approach to tree ring standardization. $\mathrm{PhD}$ Thesis, University of Arizona, United States of America.

Costa MS, Ferreira KEB, Botosso PC, Callado CH. 2015. Growth analysis of five Leguminosae native tree species from a seasonal semidecidual lowland forest in Brazil. Dendrochronologia 36: 23-32.

Evans JA, Gasson PE, Lewis GP. 2006. Anatomy of the Mimosoideae (Leguminosae). Iawa Journal Supplement 5: 1-117.

Ferreira L. 2002. Periodicidade do crescimento e formação da madeira de algumas espécies arbóreas de florestas estacionais semidecíduas da região sudeste do Estado de São Paulo. MSc Thesis. Universidade de São Paulo, Brazil.
Ferreira W, Botelho S, Davide A, Faria J. 2007. Avaliação do crescimento do estrato arbóreo de área degradada revegetada à margem do Rio Grande, na Usina Hidrelétrica de Camargos, MG. Revista Árvore 31: 177-185.

Piptadenia in Flora do Brasil 2020 em construção. Jardim Botânico do Rio de Janeiro. <http://floradobrasil.jbrj.gov.br/reflora/floradobrasil/ FB31387>. 18 Mar. 2016.

Fritts HC. 1976. Tree rings and climate. New Jersey, The Blackburn Press.

Hayden B, Greene DF, Quesada M. 2010. A field experiment to determine the effect of dry-season precipitation on annual ring formation and leaf phenology in a seasonally dry tropical forest. Journal of Tropical Ecology 26: 237-242.

IBGE - Instituto Brasileiro de Geografia e Estatística. 2012. Manual Técnico da Vegetação Brasileira, 2nd edn. Rio de Janeiro, IBGE.

Lima HC, Pessoa SVA, Guedes-Bruni RR, et al. 2006. Caracterização fisionômico-florística e mapeamento da vegetação da Reserva Biológica de Poço das Antas, Silva Jardim, Rio de Janeiro, Brasil. Rodriguésia 53: 369-389.

Lisi CS, Tomazello-Filho M, Botosso P, Roig FA. 2008. Tree-ring formation, radial increment periodicity, and phenology of tree species from a seasonal semi-deciduous forest in southeast Brazil. Iawa Journal 29: 189-207.

Longui EL, Bufolo A, Aguiar OT, Lima IL, Florsheim SMB. 2009. Anatomia comparada do lenho de Piptadenia gonoacantha (Mart.) J.F.Macbr. em dois tipos de vegetação. Hoehnea 36: 715-724.

Martínez-Ramos M, Alvarez-Buylla E. 1998. How old are tropical rain forest trees? Trends in Plant Science 3: 400-404.

Moraes LFD, Assumpção JM, Luchiari C, Pereira TS. 2006. Plantio de espécies arbóreas nativas para a restauração ecológica na Reserva Biológica de Poço das Antas, Rio de Janeiro, Brasil. Rodriguésia 57: 477-489.

Moraes LFD, Campello EFC, Pereira MG, Loss A. 2008. Características do solo na restauração de áreas degradadas na Reserva Biológica de Poço das Antas, RJ. Ciência Florestal 18: 193-206.

Pereira TS, Costa MLMN, Moraes LFD, Luchiari C. 2008. Fenologia de espécies arbóreas em Floresta Atlântica da Reserva Biológica de Poço das Antas, Rio de Janeiro, Brasil. Iheringia 63: 329-339.

Pscheidt JW, Ocamb CM. 2016. Pacific Northwest Plant Disease Management Handbook [online]. Oregon State University. <http:// pnwhandbooks.org/plantdisease>. 3 May 2016.

Roig FA. 2000. Dendrocronologia en América Latina. Mendoza, EDIUNC.

Rozendaal DMA, Soliz-Gamboa CC, Zuidema PA. 2011. Assessing longterm changes in tropical forest dynamics: a first test using tree-ring analysis. Trees 25: 115-124.

Sansevero JBB. 2008. Processos de regeneração em Mata Atlântica: uma comparação entre áreas naturais e plantios de restauração ecológica na Reserva Biológica Poço das Antas, Rio de Janeiro. PhD Thesis, Instituto de Pesquisas Jardim Botânico do Rio de Janeiro, Brazil.

Sansevero JBB, Prieto PV, Moraes LFD, Rodrigues PJFP. 2011. Natural regeneration in plantations of native trees in lowland Brazilian Atlantic forest: Community structure, diversity, and dispersal syndromes. Restoration Ecology 19: 379-389

Schulman E. 1956. Dendroclimatic changes in semiarid America. Tucson, University of Arizona Press.

Tomazello-Filho M, Hansen N, Cury G, Lisi CS. 2004. Anatomical features of increment zones in different tree species in the State of São Paulo, Brazil. Scientia Forestalis 66: 46-55.

Walter H, Lieth H. 1960. Klimadiagramm Weltatlas. Jena, Gustav Fischer Verlag.

Weiner J. 2001. The nature of tree growth and the "age-related decline in forest productivity". Oikos 94: 374-376.

Worbes M. 1995. How to measure growth dynamics in tropical trees: a review. Iawa Journal 16: 337-351.

Worbes M. 1999. Annual growth rings, rainfall-dependent growth and long-term growth patterns of tropical trees from the Caparo Forest Reserve in Venezuela. Journal of Ecology 87: 391-403.

Worbes M, Junk WJ. 1999. How old are tropical trees? The persistence of a myth. Iawa Journal 20: 255-260. 